\title{
Economic Support of the Policy of Transition to Sustainable Development of the Territories of the Russian North
}

\author{
Irina Politkovskaya ${ }^{1}$, Daniil Khvichiya ${ }^{1}$, and Larisa Artamonova ${ }^{2}$ \\ ${ }^{1}$ Moscow Automobile and Road Construction State Technical University (MADI), 125319, 64 \\ Leningradsky av., Moscow, Russia \\ ${ }^{2}$ Institute of Economics and Crisis Management, 117312 53/2 Vavilova Street, Moscow, Russia
}

\begin{abstract}
The role of the northern territories of the Russian Federation is explained by the presence of proven mineral reserves - up to two thirds of national minerals, including over nine tenths of natural gas, three quarters of oil, the whole diamonds deposits, eight tenths of gold. The exploitation of the northern territories of Russia acquires a special role due to the fact that the export of mineral resources brings more than two thirds of all its foreign trade income. The transition to sustainable development for the Russian North means resolving old and new problems associated with environmental degradation and the infringement of the interests of local minorities. The problem of transition to sustainable development is especially acute in oil and gas producing regions, where economic, social and environmental issues are closely related. Sustainable development of resource regions of the Russian North is possible only with the active support of the state, subject to the creation and consistent implementation of a regional policy for sustainable development, which. This article formulates the main directions of the state policy for the transition to sustainable development of the northern territories, contributing to the achievement of the strategic goals of balanced and socially responsible subsoil use.
\end{abstract}

\section{Introduction}

The mineral resource territories in Russia include regions in which mining and oil and gas extracting dominates the formation of GDP, in the tax revenues of regional authorities, and also creates up to half of the population's employment. In the Russian North, these territories currently include: Khanty-Mansiysk, Yamalo-Nenets, Nenets Autonomous Districts, the Komi Republic and others.

The main problem of the mineral resource regions of the North is associated with the instability of economic development, since the economies of the regions are completely dependent on world prices for minerals and their production volumes, as well as on the prospects for the inevitable depletion of deposits.

The problems of transition to sustainable development of the Russian northern territories are also caused by the dependence of their economy on national and international vertically integrated industrial structures. As mineral deposits become depleted, transnational companies of Russia will gradually reduce production, which will make these territories 
depressed, disrupted by the ecosystem and destroyed by the traditional way of life of the local population.

\section{Materials and Methods}

In the context of the transition of the Russian economy to a neo-industrial type of development, which is characterized by rapid innovative modernization of basic industries, digitalization of the industrial complex [1-4], the issue of sustainable development of the most underdeveloped territories - mineral-resource clusters of the Russian North, - is relevant.

To date, there are some studies proving the need for state regulation of the mineral resource territories of the North, the creation of an environmental protection system and the culture of small nations, together with corporations developing mineral deposits [5-7]. The general directions of stabilization and the transition to sustainable development of the northern territories are as follows:

- creation of special regional stabilization funds;

- strengthening the social and environmental blocks in the economic policy of the state in relation to the northern territories, concern for the fate of small single industry mineral resource clusters;

- diversification of the economy of the northern territories, increasing the degree of processing of mineral raw materials.

So, for example, in the Canadian North in the 1980s, attempts were made to rescue the declining deterioration of some Labrador centers of iron ore, mining and forestry centers in the provinces of Alberta and British Columbia, as well as the search for new livelihoods for the population [8]. A set of measures to support economic development included the processing of raw materials mined in neighboring areas; development of trade and transport activities, small business, tourism.

In particular, in the province of Alberta, where oil and gas production accounted for $85 \%$ of the gross regional product, high-tech industries were introduced. As a result, by 1989 about 360 small knowledge-intensive enterprises were operating here. In Alaska, enterprises for the deep processing of oil (petrochemicals) have long been created and are being created [8]. A diversified economy has been established in the northern regions of Norway and Sweden.

In most foreign countries, the role of the state in the development of the northern territories is the creation of stabilization funds to support single-industry raw material clusters. So, in Alaska already in 1990, the Permanent Fund amounted to 10.5 billion dollars (today it is more than 25 billion dollars) [8]. The main, but not the only purpose of the Fund is to help the population and the economy in a crisis situation. He played a huge role in overcoming the crisis of 1985-1988, when oil prices fell sharply, and more than 20 thousand people lost their jobs. The money of this fund were used to subsidize enterprises, pay unemployment benefits, and compensate the population for the effects of inflation. The fund's investments were organized in treasury bonds, annually bringing interest to the population of these territories. In 1990, the Oil fund was created in Norway, accumulating oil revenues and investing them in government bonds and shares of companies in other countries. This fund was created using the experience of the Kuwait Oil fund to regulate the economy during the period of rising oil prices, as well as to ensure future generations [8].

Currently, the main content of the state policy for sustainable development of the mineral extracting territories of the North is associated with the widespread use of indirect measures of economic regulation instead of direct prescriptive methods: research, industrial, sociocultural, technical and environmental programs. With regard to the conservation of nature and culture of the small populations of the North, various financial and organizational forms are used in developed countries to preserve original environment and traditional economic 
structure. Despite a slight reduction in the financing of social programs in the economy (neoconservatism) by the Nordic countries since the 1970s, social programs to support the resource regions of the North did not decrease.

Tax support measures for resource regions of the North are also diverse. For example, in the USA, the tax system embeds a territorial differentiation in types and rates of taxes, leaving most of the fees (license, rental, and also taxes themselves) in these territories, taking a smaller part to the federal budget.

It should also be noted that the policy on the development of the North's territory abroad is adaptable, since its measures vary flexibly depending on specific problems, for example, depletion of mineral deposits [9]. However, the vector of environmental protection and supporting the culture of small populations inhabiting the northern territories remains unchanged.

\section{Results and Discussion}

The transition to sustainable development of mineral resources of the Russian North is advisable to carry out in the following main directions of state policy:

- protectionism in relation to industries whose functioning cannot be based solely on the principles of market competition;

- creation of regional financial funds and transfer to them part of the income from mining;

- the organization of attractive living conditions and the implementation of traditional activities of small populations, especially in places of intensive exploitation of mineral deposits;

- establishing relationships between regions with commodity corporations based on compliance with the principles of sustainable development;

- the application of a differentiated policy in relation to small populations, in particular the hiring of their representatives for mining companies, depending on when the mineral deposits are exhausted;

- diversification of the economy, including the creation of manufacturing and auxiliary industries;

- increased investment in the development of high-tech industries, expansion of the service sector.

The use of protectionism by the state in relation to the economy of the Northern resource regions should become the main principles of the policy of transition to sustainable development. The essence of protectionism is to maximize benefits for manufacturing industries in the Northern territories. Thus, it is possible to provide state needs with products manufactured at enterprises of the Russian North that are not related to the extraction of raw materials. Protectionism also means creating the most favorable conditions for the development of industrial production and the socio-cultural environment of the local populations, in harmony with the processes of preserving the environment. It is important to take into account the principle of maintaining the rational number of small populations of the North, in particular, to ensure the displacement of the population of ecologically unfavorable areas to new centers of industrial and cultural development of the North.

Sustainable development as an element of the industrial growth of the North should be carried out in such a way that the depletion of all natural resources takes place against the background of the conservation of the natural environment and the protection of traditional types of economic activity, which in the future will represent the basis of the vital activity of small populations [10]. To this end, it is important to ensure the rapid development of infrastructure, primarily, transport and communications [11-13].

An important element of the policy of transition to sustainable development in the Russian North is the formation and implementation of federal and regional targeted programs using 
the maximum preferential tax regime and subsidized lending to promising local industry facilities. For the Russian North, it is necessary to create a strategy for the development of its extractive regions during the period of depletion of natural resources for the next 20-25 years. For this, it is now necessary to provide the regional development with strategic plans of support for the local populations while reducing resource extraction, up to a complete cessation. This means a transition to a strategy of balanced social, environmental and economic development of the mineral resource regions of the North. A key tool for implementing such a strategy is the formation of a socio-economic and strategic plans aimed at linking long-term environmental and economic guidelines and proposing specific measures to achieve them.

When developing specific tools for balanced strategic planning, determining priorities and conditions for its implementation, it is important to take into account the characteristics of the socio-economic status of each particular region [14-16].

Oil and gas production by Russian companies is currently concentrated mainly in the regions of the North. The need to strengthen state regulation of the development of northern oil and gas clusters is due to the following:

- special vulnerability of northern natural ecosystems;

- coincidence of the place of residence of small populations and occupation by traditional types of economy with the occurrence of oil and gas resources and intensive oil and gas production;

- maintaining the sustainable development of the Northern territories in order to provide normal living conditions of the indigenous population in the future.

Regulation of the oil and gas sector as the most profitable segment of the Russian economy should be accompanied by the requirements for the transition of territories in which oil and gas production is concentrated to sustainable development. For this, it is important to harmonize the relations of ownership on natural resources between the federal government and the regions, to create a justified system for the seizure and distribution of resource rents and income from the sale of oil and gas abroad and within the country, taking into account the interests of the Northern territories and their small populations. In this it is necessary to use the experience of Norway in protecting the interests of small peoples living in the northern territories with the help of a fair legislative system.

The stability of the oil and gas complex has been proven by Norway's success in economic and social development. This country has created an effective model of state regulation of gas oil production, reducing environmental damage and preserving the culture of the Northern people. The importance of using the Norwegian experience in regulating the oil and gas sector of the national economy lies in the effective distribution of indirect and direct regulation in all areas of interaction between the state and the oil and gas business, such as state management of hydrocarbon production, transportation and sales, licensing of raw materials extraction, taxation and interactions with foreign producers.

The system of state regulation of the oil and gas sector includes specific and general forms of regulation. Specific forms of regulation are the following:

- licensing;

- regulation of production;

- regulation of certain (monopoly) activities (transportation of hydrocarbons by trunk pipelines).

The general forms of regulation are the following:

- tax policy;

- price regulation;

- regulation in the field of scientific and technological progress.

A special place among the forms of regulation of the oil sector is occupied by licensing of subsoil users - oil and gas companies. The development of an administrative licensing 
system for oil and gas fields will limit the monopoly on the exploitation of natural resources and provide real control over compliance with the established federal and local laws.

A key form of state regulation of the oil and gas industry in the Northern territories is to ensure the direct participation of the state as an investor in the production of hydrocarbons. State investment in financial and industrial assets are an integral element of the economic policies of developed countries. Despite the not always high efficiency of state investments in industry, they are able to ensure that the development of raw materials production is tied to environmental problems solving, while maintaining and increasing the competitiveness of national companies in the domestic and foreign markets. The main form of public investment in leading oil producing countries are state corporations, which constitute institutional protection against the expansion of international oil and gas corporations in the country's economy.

\section{Conclusion}

Thus, the sustainable development of the extractive regions of the Russian North is associated with the establishment of a special state policy, with the development of forms and methods of state regulation of environmental management, reflecting the specifics of mineral resource regions and taking into account the ecological and socio-cultural characteristics of the habitat of small populations of the North. In order to formulate a policy for the transition of the Russian north to sustainable development, a balanced approach is required, which denies the desire to ensure immediate income from the exploitation of natural resources.

\section{References}

1. S. Zhironkin, D. Khloptsov, N. Skrylnikova, I. Petinenko, O. Zhironkina, E3S Web Conf., 41, 04010 (2018)

2. S. Zhironkin, S. Demchenko, G. Kayachev, E. Taran, O. Zhironkina, E3S Web Conf., 105, 03008 (2019)

3. V.V. Guzyr', Economics and Innovation Management, 4, 4-19 (2019) DOI: 10.26730/2587-5574-2019-4-4-19

4. S. Zhironkin, O. Aleshina, V. Gorev, Y. Gunyakov, O. Zhironkina, E3S Web Conf., 105, 04001 (2019)

5. S. Zhironkin, M. Cehlar, V. Zhironkin, E3S Web Conf., 134, 2019 (03013)

6. V. Zhironkin, J. Janocko, E3S Web Conf., 134, 02002 (2019)

7. M. Cehlár, J. Janočko, Z. Šimková, T. Pavlik, M. Tyulenev, S. Zhironkin, M. Gasanov, Resources, 8:1, 21 (2019)

8. L. Larchenko, T. Nikolaeva, RSPU Bul.,11, 270-278 (2005)

9. O. Litvin, M. Tyulenev, S. Zhironkin, S. Prokopenko, Acta Montanistica Slovaca, 22:2, 146-152 (2017)

10. T.V. Kiseleva, V.G. Mikhailov, Economics and Innovation Management, 4, 70-78 (2018) DOI:10.26730/2587-5574-2018-4-70-78

11. V. Frolova, O. Dolina, T. Shpilkina, E3S Web of Conf., 105, 01054 (2019)

12. Dotsenko, E., E3S Web of Conf., 21, 04013 (2017)

13. T. Skryl, E. Shavina, E. Dotsenko, E3S Web Conf., 105, 04049 (2019)

14. T. Snegireva, G. Kayachev, A. Falaleev, S. Kurgansky, E3S Web Conf., 134, 03014 (2019) 
15. N. Zaruba, T. Fraltsova, T. Snegireva, E3S Web Conf., 21, 04028 (2017)

16. N. Kudrevatykh, T. Snegireva, A. Tselischeva, E3S Web Conf., 15, 04006 (2017) 